\title{
25. HIGH-RESOLUTION SEQUENCE STRATIGRAPHY, CONDENSED SECTIONS, AND FLOODING EVENTS OFF THE GREAT BARRIER REEF: 0-1.5 MA ${ }^{1}$
}

\author{
Craig R. Glenn, ${ }^{2}$ John D. Kronen, Jr., ${ }^{2}$ Phillip A. Symonds, ${ }^{3}$ Wuchang Wei, ${ }^{4}$ and Dick Kroon ${ }^{5}$
}

\begin{abstract}
Examination of seismic reflection and core data between Sites 819 and 821 provides information about patterns of sedimentation that result from repetitive fluctuations in relative sea level and climatic perturbations. On the basis of sequencestratigraphic interpretations, we identify nine sequences bounded by sequence boundaries; each sequence contains lithologically distinct and relatively thin units that have been interpreted as condensed sections. Because of very high mixed carbonate-siliciclastic sedimentation rates in this region, resolution of third-, fourth-, and fifth-order changes of sea level is recognized. One predominant condensed section is identified within each sequence and is associated with the maximum flooding surface of that sequence. These condensed sections are marked by increases in abundance of quartz, clay, and shallow-water bioclasts; increases in nonreworked pristine glauconites; decreases in total carbonate abundance; and increases in magnetic susceptibility. Increases in glauconite have been interpreted to indirectly reflect relative decreases in sedimentation rates, whereby sediment residence time is prolonged within suboxic bacterial degradation zones. Increases in bioclasts within transgressive systems tracts are attributed to relatively rapid buildups of shallow-water reefal communities that accompanied punctuated flooding events; during these times shallow-water carbonate growth accelerated as reefal communities built upward rapidly to keep up with rising sea level. Increases in quartz and clay contents during maximum flooding are thought to be tied to sediment starvation, whereby background clays and quartz contents are concentrated. Decreased accommodation potential during relative highstand phases promoted progressive highstand systems tract progradation and sedimentation of reworked glauconites and terrigenous sands, silts, and clays. These depositional phases also are marked by increases in bioclastic sands that accompanied the progradational, seaward building events.
\end{abstract}

\section{INTRODUCTION}

The depositional characteristics and lithologies of condensed sections have been variously described in the geologic literature for decades. They are significant because they represent long periods of geologic time within a condensed lithologic unit. Condensed sections are thin marine units of pelagic to hemipelagic sediments characterized by very low sedimentation rates, and are areally most extensive at the time of maximum marine transgression; they are coincident with marine flooding surfaces and, in particular, surfaces of maximum flooding. These sections are associated with apparent marine hiatuses, may occur as omission surfaces or marine hardgrounds, and are thought important because they tie the temporal stratigraphic framework found in open-ocean microfossil zonations to the physical stratigraphy of sequences in shallower/landward sections (Loutit et al., 1988). Condensed sections also are often characterized by authigenic minerals (glauconite, siderite, and phosphorite) and clay minerals and may contain diverse and abundant planktonic and benthic microfossil assemblages, as well as wind-borne detritus (Loutit et al., 1988; Vail et al., 1991). In carbonate depositional settings, drowning of the shelf that accompanies marine flooding results in sediment starvation, which can concentrate authigenic minerals and form a condensed section that is often a shaly micritic package (Haq, 1991). In open ocean settings below the calcite compensation depth, maximum flooding surfaces coincide with dissolution surfaces (Haq, 1991).

Here we consider the style and significance of the hallmarks of condensed sections that are present in forereef sediments of the upper

\footnotetext{
'McKenzie, J.A., Davies, P.J., Palmer-Julson, A., etal., 1993. Proc. ODP, Sci. Results. 133: College Station, TX (Ocean Drilling Program).

${ }^{2}$ Department of Geology and Geophysics, School of Ocean and Earth Science and Technology, University of Hawaii, Honolulu, HI 96822, U.S.A.

${ }^{3}$ Division of Marine Sciences, Bureau of Mineral Resources, Geology and Geophysics, P.O. Box 378, Canberra City, ACT 2601, Australia.

${ }_{4}^{4}$ Scripps Institution of Oceanography, La Jolla, CA, 92093, U.S.A.

5 Department of Geology and Geophysics, University of Edinburgh, Edinburgh, EH9 3JW, United Kingdom.
}

slope and outer shelf of the Great Barrier Reef (GBR) transect, Leg 133 . Sites 819 through 821 . We discuss their relationship to timing and development with respect to sequence-stratigraphic architecture, their lithologic character, and their significance to interpretations of sea-level changes that affected the GBR margin in Pleistocene time. Sedimentation rates along the margin are high, and the average duration of many of the sequences appears to be clearly related to cyclicity in the Milankovitch waveband and to third-, fourth-, and fifth-order cycles of sea-level change (see Glenn et al,, this volume). They thus serve as an excellent, expanded record (because of high sedimentation rates) within which to investigate sequence stratigraphy and sequence condensation in a mixed depositional setting. We provide an interpretation of the condensed sections present in these sediments and discuss the synthesis of our interpretations using the concepts of seismic and sequence-stratigraphic analyses.

\section{METHODS}

\section{Sequence-Stratigraphic Methodology}

The sequence is the fundamental unit of sequence stratigraphy; it is made up of repetitive, genetically related strata bounded by surfaces of erosion or nondeposition (unconformities) and their correlative conformities (Mitchum et al., 1977). In general, sequence boundaries are surfaces marked by a basinward shift of facies and onlap of overlying strata (Fig. 1) (Van Wagoner et al., 1988). Systems tracts are linkages of contemporaneous depositional systems (Brown and Fisher, 1977) that designate up to three subdivisions within a sequence; they are defined on the basis of types of bounding surfaces and their position within a sequence (Fig. 1; cf. Van Wagoner et al., 1988; Vail et al., 1991). Note that the time of initiation of a systems tract has been interpreted as a function of the interaction between eustasy, sediment supply, and tectonic subsidence, and, further, that each is associated with a specific segment of the eustatic curve, although it has not been defined on the basis of that association (Fig. 1; Van Wagoner et al., 1988; Posamentier et al., 1988). For this study we have assumed that tectonic subsidence for the interval 


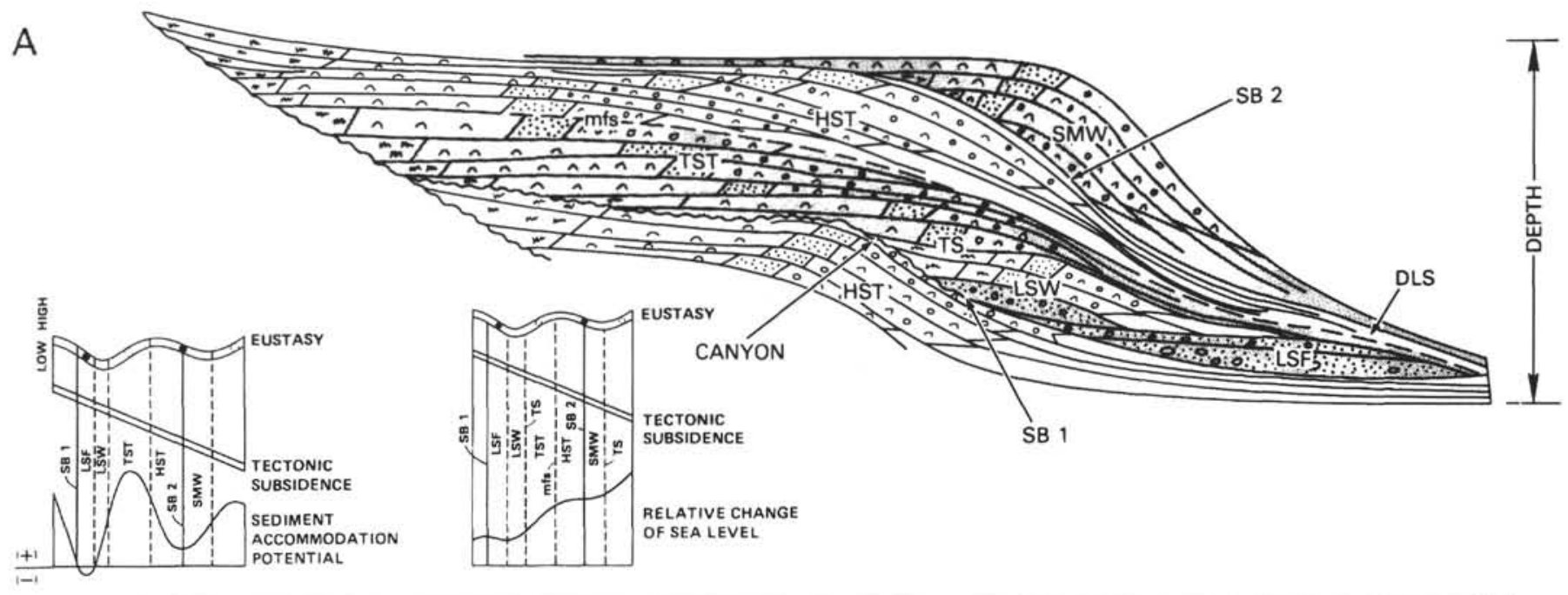

B

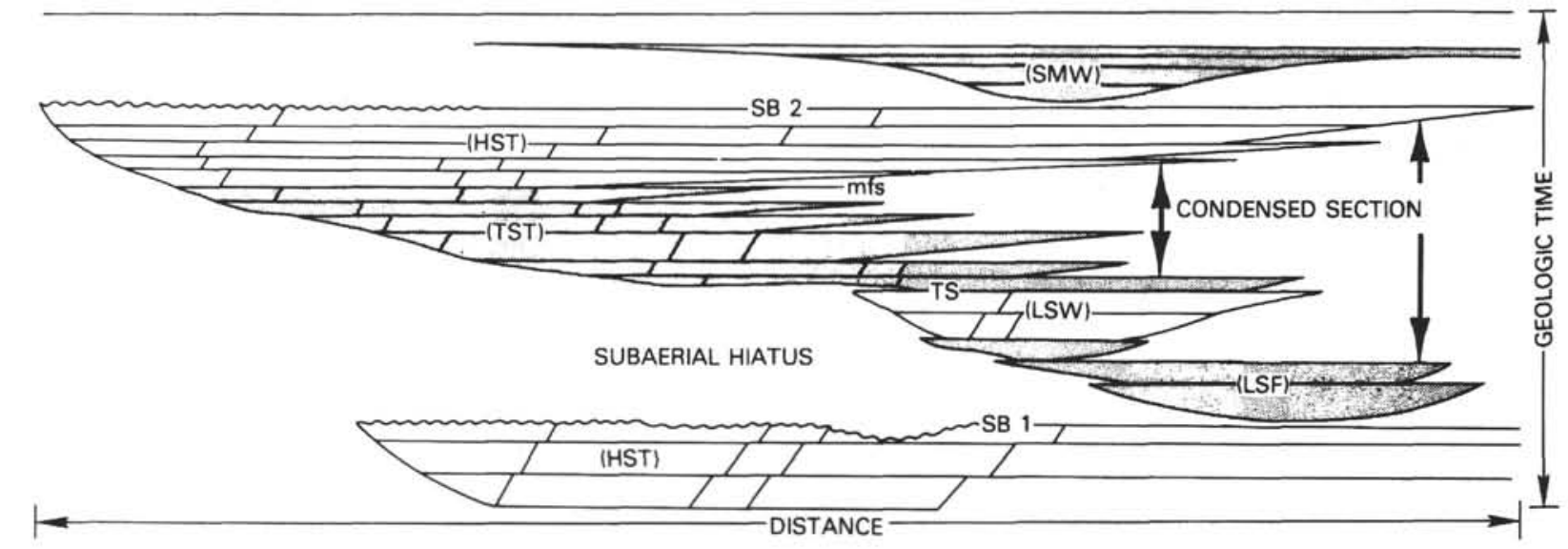

\section{LEGEND}

\section{SURFACES}

(SB) SEQUENCE BOUNDARIES

(SB 1) = TYPE-1

(SB 2) $=$ TYPE-2

(DLS) DOWNLAP SURFACES

$(\mathrm{mfs})=$ maximum flooding surface

(TS) TRANSGRESSIVE SURFACE

(First flooding surface above maximum regression!

\section{SYSTEMS TRACTS}

HST = HIGHSTAND SYSTEMS TRACT

TST $=$ TRANSGRESSIVE SYSTEMS TRACT

LST = LOWSTAND SYSTEMS TRACT

LSF $=$ LOWSTAND FAN

LSW $=$ LOWSTAND WEDGE

$S M W=$ SHELF MARGIN WEDGE SYSTEMS TRACT

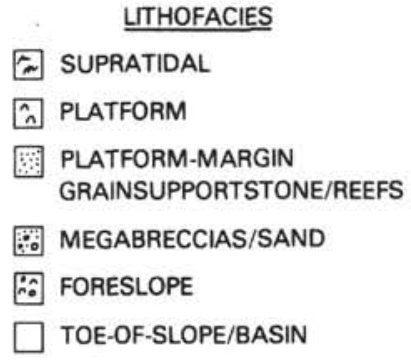

Figure 1. Summary schematic diagram showing distribution of the various stratigraphic surfaces, systems tracts, and lithofacies in a carbonate sequence framework, both in depth (A), and in time (B) (from Sarg, 1988). Note the lateral extent of sequence condensation in time and the stratigraphic position of the condensed section at the maximum flooding surface in depth. Also note the rapid increase in sediment accommodation potential associated with the transgressive systems tract. Lithofacies interpretations are those from Sarg (1988) for an idealized carbonate depositional setting.

studied is thermal and linear (cf. Katz and Miller, this volume). Condensed sections typically are formed at the maximum flooding surface between formation of transgressive systems tract deposits and overlying highstand systems tract deposits (Fig. 1). In a typical shelf/slope profile, a condensed section can range from a fossil- and glauconiterich zone on the proximal shelf to a biostratigraphic gap toward the basin (Haq, 1991). This condition appears to hold true at the GBR margin, where at Site 819 it is relatively barren of glauconite compared with Site 821 (see below).
Before Leg 133, Symonds et al. (1983) originally divided the package of sediments off the central GBR into five major seismic depositional sequences that were separated by unconformities (down to $\sim 1.5$ s). The upper four sequences were interpreted as major phases of low sea-level progradation, the oldest one being of Oligocene age. Feary et al. (1990) interpreted these sediments as latest Miocene to Holocene progradational sequences overlain by aggradational sequences.

Following Leg 133, we developed a sequence-stratigraphic analysis of the GBR transect based on principles and procedures of se- 
quence stratigraphy (cf. Van Wagoner, 1988; Posamentier et al., 1988; Posamentier and Vail, 1988; Sarg, 1988; Vail, 1990; Van Wagoner et al., 1990; Vail et al., 1991; Haq, 1991). This procedure involves integration of seismic reflector configurations with downhole wireline data, downcore sedimentology and geochemistry, biostratigraphy, and magnetic susceptibility.

Our seismic/sequence-stratigraphic interpretation of Bureau of Mineral Resources (BMR) seismic Line 75/043 (Part T) facilitated correlation between Sites 821 and 819 and identification of important stratigraphic surfaces. Parts H, J, L, N, and P of Line 75/043 also were analyzed. These lines are part of a data set of about $131 \mathrm{~km}$ of 24-channel, 80 -in. ${ }^{3}$ water-gun, magnetic, and bathymetric data collected by the BMR during its northeastern Australia Rig Seismic site survey in 1987.

\section{Sedimentologic and Geochemical Methodology}

Sedimentary variations in cores from Sites 819 and 821 were defined by the following parameters: percentage total carbonate; percentage $>63-\mu \mathrm{m}$ fraction of glauconite, siliciclastics (predominantly of quartz and feldspar), nonforaminifer bioclasts (predominantly of shell fragments-mostly mollusks, spicules, coralline algae and bryozoans, and siliciclastic grains); percentage total foraminifers, nannofossils, and tunicates; magnetic susceptibility; and downhole variations in velocity, resistivity, and gamma-ray emission. A coarse fraction ranking also was constructed on the basis of the percentage of grains visually estimated to be greater than $125 \mu \mathrm{m}$ ( $\geq$ fine sand). All smear slides and smear slide analyses for each component were made by one operator to ensure the internal consistency of the results. Mineral identifications were augmented by electron microprobe analysis of grain mounts. Total carbonate was determined by acidification-tied coulometric titration (cf. Huffman, 1977; Engleman et al., 1985). Total carbonate concentrations represent a combined data set of shipboard and shore-based results. Nannofossil abundances were determined from samples spaced approximately every $1.5 \mathrm{~m}$. Magnetic susceptibility and wireline data were collected during shipboard operations. Magnetic susceptibility is the ratio of induced magnetization to an applied weak magnetic field and is proportional to magnetic mineral concentration, which is usually a trace component of the terrigenous fraction of sediments, but which also may be affected by glauconite and pyrite (cf. Glenn et al., this volume).

\section{RESULTS}

\section{Sequences and Systems Tract Assignments}

Sequence boundaries, maximum flooding surfaces, and transgressive surfaces are significant stratigraphic surfaces that can be traced out as time lines on seismic reflection profiles (Vail et al., 1977). These surfaces have been annotated on BMR seismic Line 75/043 (Part T) (Fig. 2) and represent our interpretation of the sequence stratigraphy of the GBR margin cored at Sites 819, 820, and 821. Employing the sequence-stratigraphic interpretation procedures outlined above, we identified nine sequences within the cored section at these sites. Sequence 6 (Fig. 2) has been further divided into three higher-order sequences (6A, 6B, and 6C). At Site 821, closest to the GBR platform edge, all nine sequences are each bound at their base and top by a sequence boundary, and each contains a transgressive systems tract (TST), capped by a downlapped surface that separates it from an overlying highstand systems tract (HST); this downlapped surface is characterized by thin units having unique sedimentologic properties (see below) and has been interpreted as the maximum flooding surface (MFS). Sequence 8 also contains a relatively thick lowstand systems tract (LST) and transgressive surface (TS) near the base of the recovered section. Site 819 , the most basinward and deepest water site of the transect, is an incomplete section compared with Site 821, because entire and partial sequences are missing. Sequence $6 \mathrm{C}$ terminates seaward of Site 820 , as does the overlying TST section of
Sequence $6 \mathrm{~B}$. One cannot resolve from the available seismic data whether these "missing" sequences are represented in Site 819 cores. Possibly, these sequences have become entirely condensed at Site 819 , or they may have been eroded and/or slumped out of the section. Further upsection, Sequences 5, 2, and 1 were interpreted as LST deposits, and their correlative TST and HST sections can be found landward of Site 819 . Sequences 3 and 4 are missing in the vicinity of Site 819 because of nondeposition, lateral diversion, or erosion of probable LST accumulations.

Sequences 9 through 6 appear to be relatively progradational deposits and, as a result, have contributed to a relative outbuilding of the margin. Sequence 8 has a thick accumulation of sediments (composed of probable prograding wedge deposits) that represents a significant episode in slope margin outbuilding. We interpret this sequence to be either a LST or a shelf margin wedge systems tract (SMW). The highstand phase of each of these sequences is also characterized by progradation and is marked at its base by downlapping reflectors along the MFS, as well as by a general thickening toward the basin. Examination of seismic lines perpendicular to seismic Line $\mathrm{T}$ shows that the concavity and downwarping of reflectors in Sequences 9 through 7 between Sites 819 and 820 result from progressive infilling of an upper-slope canyon (see Feary et al., this volume). In contrast, Sequences 5 through 1 appear to be aggradationally biased continental shelf and upper-slope deposits, as evidenced at Sites 821 and 820. Aggradational deposition is absent at Site 819, but correlatively equivalent lowstand deposits are represented by Sequences 5 , 2 , and 1 .

\section{Combined Sedimentologic and Sequence-Stratigraphic Results}

The sediments recovered between Sites 819 and 821 are predominantly unlithified, water-saturated mixed carbonate-siliciclastic sediments composed of calcareous mudstones, wackestones, and packstones that grade to carbonate oozes and chalks. Predominant carbonate components are calcareous nannofossils, micrite, planktonic and benthic foraminifers, and shallow-water bioclasts. Mixed with these are varying percentages of terrigenous clay, quartz, feldspar, and other detrital grains. This terrigenous component is dominated by fine clay and some silt, with relatively minor proportions being greater than 63 $\mu \mathrm{m}$; the sand fraction is predominantly $63-$ to $125-\mu \mathrm{m}$, fine-grained quartz. At Site 821, the most proximal to the reef edge, the sediments are rich in glauconite-infilled microfossils (see below).

\section{Carbonate-Magnetic Susceptibility Variations}

Figures 3 and 4 show the relationship among calcium carbonate, magnetic susceptibility variations, and other important sedimentologic and geochemical parameters recorded at Sites 819 and 821 . Note that at Site 821 the character of each of these parameters appears to be bracketed in a general way by each of the sequences delineated. The total carbonate curve paired with magnetic susceptibility reveals a well-defined pattern of cyclic sedimentation of bundles of relatively low carbonate (low insoluble residues) and high magnetic susceptibility. At Site 821 , these bundles tend to form couplets roughly correlating with the maximum flooding surfaces and, to a lesser extent, with the highstand systems tracts identified from our sequence stratigraphic analysis (Fig. 4). The rhythmic variations of these bundles are tracked fairly closely by variation in the percentage $>63-\mu \mathrm{m}$ fraction and gamma-ray intensity at Site 819 , and by the variations in $>63-\mu \mathrm{m}$ siliciclastics at both sites. These factors strongly suggest that the thickening of carbonate/magnetic susceptibility bundles is a result of periodic increases of terrigenous materials to the margin. In addition, the relationship of these bundles to the internal architecture of sequences is especially clear at Site 821 (Fig. 4); the carbonate/magnetic susceptibility bundles correlate with two discrete phases during the development of each TST/HST couplet, one in association with downlapped maximum flooding surfaces when clays reach a maxima, 


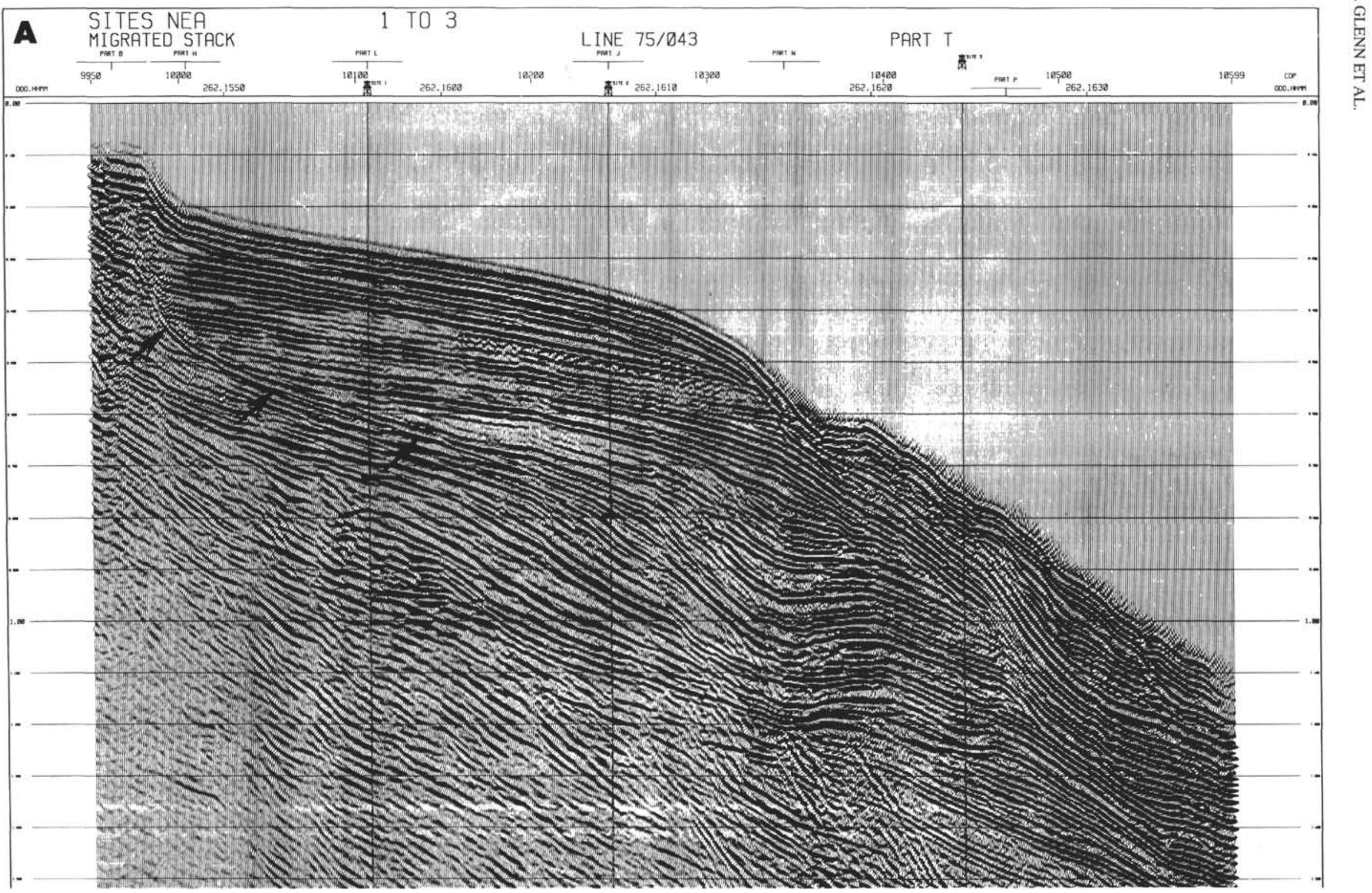

Figure 2. A. Seismic reflection profile BMR Line 75/043, Part T, migrated stack, arrows point to seafloor multiple. B. Sequence-stratigraphic interpretation. See text for discussion. Site 821 depth scale is shown displaced to left of site. Heavy bold line indicates probable slump surface. $T D=$ total depth. 


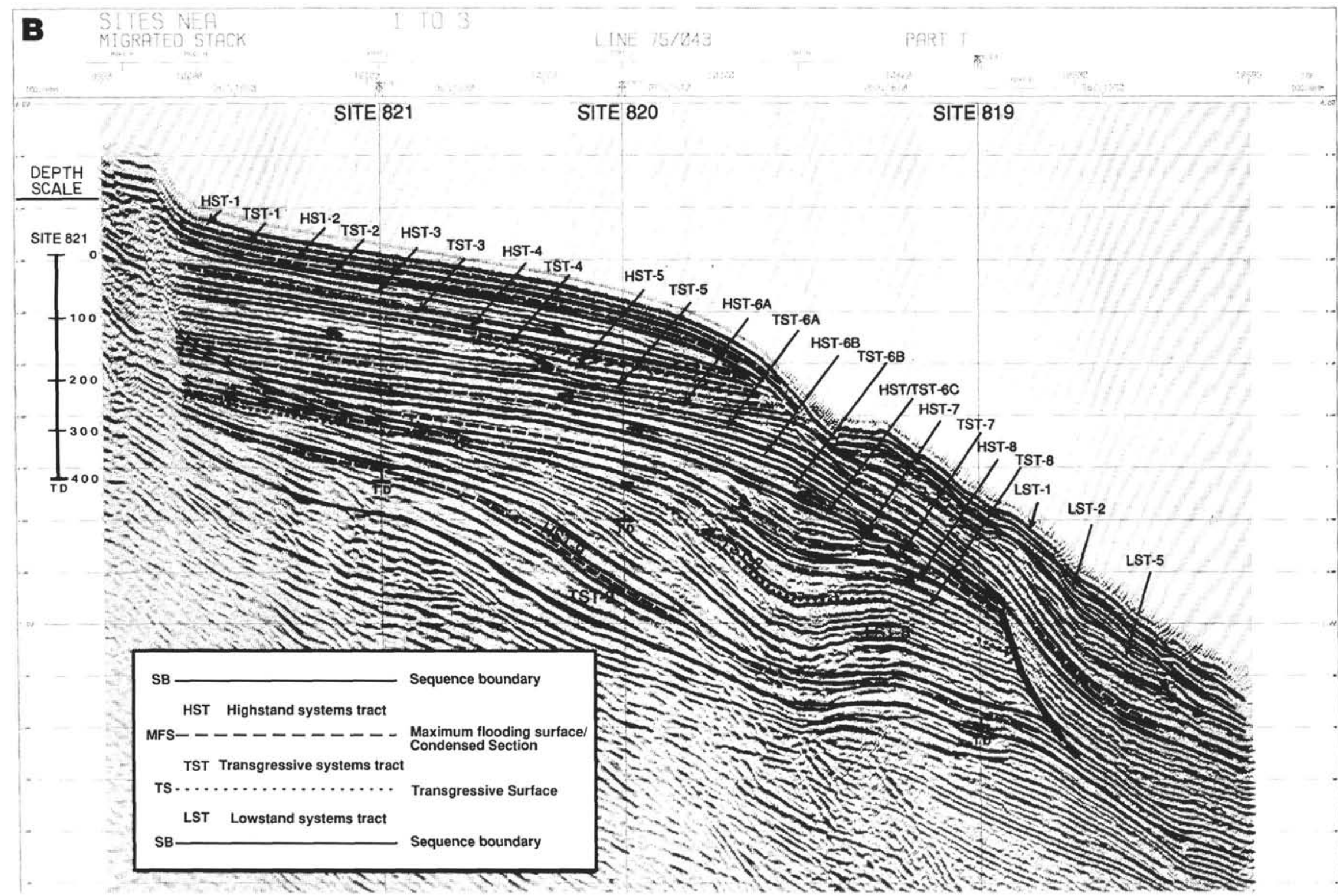

Figure 2 (continued). 


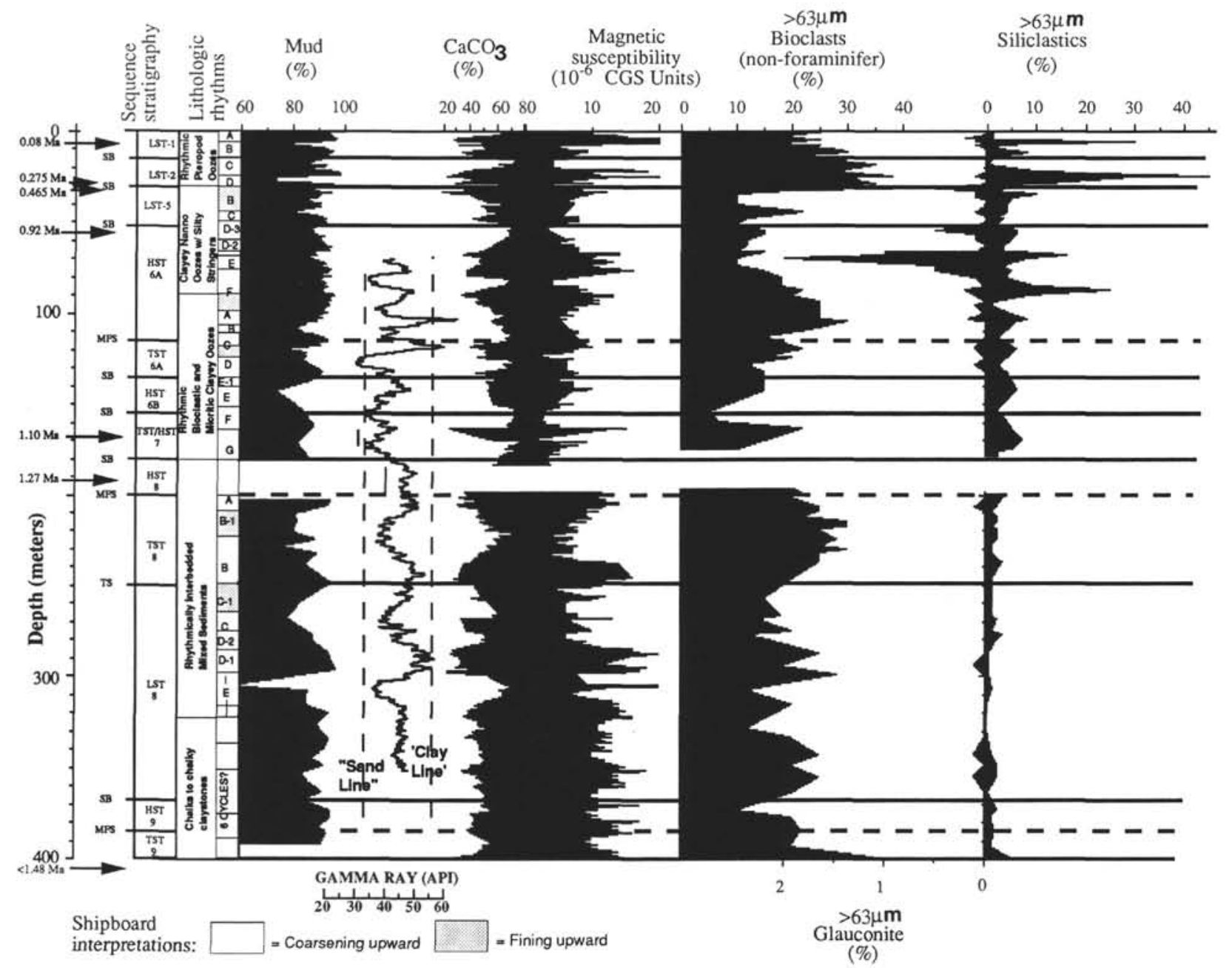

Figure 3. Sedimentary, geochemical, gamma-ray, and sequence-stratigraphic data for Hole 819A. Coarsening and fining upward cycles are indicated. Nannofossil datums of Table 1 also are shown.

and the other with late highstand systems tract progradation. At Site 821 , therefore, these bundles appear to mimic relative changes in sea level. At Site 819, however, the correspondence of variations to sequence architecture is very poor because of normal faulting (and/or slumping), and depositional thinning. In addition, the dominance of LSTs (Fig. 2B) at this more seaward site makes the correlation between Sites 819 and 821 difficult.

\section{Glauconite}

Maximum flooding surfaces and later highstand progradational events also are matched by discrete pulses of glauconite (and minor siderite and iron oxyhydroxide) sedimentation of two different types. Along downlapped surfaces, which traditionally are interpreted as surfaces of maximum flooding and sequence condensation (cf. Loutit et al., 1988), the proportions of glauconite are abundant and particularly "pristine" (Fig. 4). These glauconites typically occur as wellpreserved, nonabraded authigenic precipitates that fill in primary intraparticle porosity, especially within foraminifer tests (Fig. 5). The tests housing these precipitates are well preserved and show little or no evidence of reworking or abrasion (Fig. 5). In addition to occurrences along downlapped surfaces, Figure 4 shows that pristine glauconites also may occur as other, subordinate yet progressively increasing, pulses that likewise correlate with increases in the width of the percentage of carbonate/magnetic susceptibility bundles, and percentage of siliciclastics and bioclasts. These are found in the trans- gressive systems tracts of Sequences $8,6 \mathrm{~B}$, and 5 , and have been interpreted to represent transgressive flooding surfaces (cf. Fig. 1). In contrast, the glauconites associated with late-stage highstand systems tract progradational events are much less abundant, show substantial evidence for considerable reworking and transport, and are usually not contained within foraminifer tests (Fig. 6). The reworked nature of the particles can be attributed to the relatively higher-energy depositional setting associated with highstand progradation that accompanied decreasing accommodation space. As discussed more fully below, these late-stage reworked glauconites also may reflect another, perhaps diminished, stage of sequence condensation associated with toplap reflector configurations.

\section{Bioclasts (Nonforaminifer)}

Accompanying increases in glauconite and siliciclastics along flooding surfaces are increases in bioclasts that were derived from shallow-water environments. At these positions, proportions of shallow-water bioclasts increase despite decreases in total carbonate contents (Fig. 4). Such increases within transgressive systems tracts are attributed to relatively rapid buildups of shallow-water reefal communities that accompanied punctuated flooding events. We suggest that, during these times, shallow-water carbonate growth accelerated as reefal communities built rapidly upward to keep up with accelerated rising sea level. These are akin to the keep-up carbonate complexes of Kendall and Schlager (1981) and Sarg (1988). Upon or 


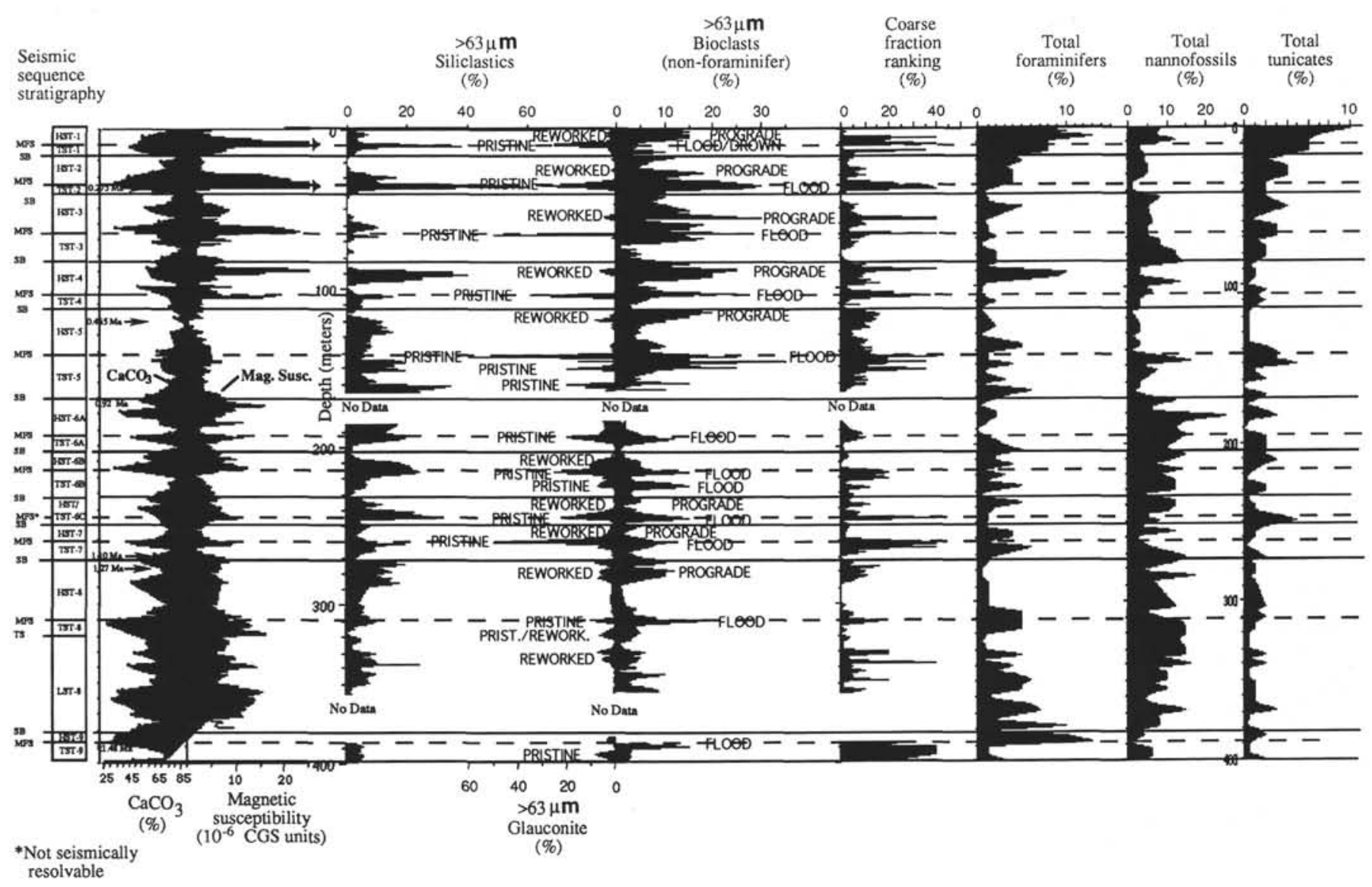

Figure 4. Sedimentary, geochemical, gamma-ray, and sequence-stratigraphic data for Hole $821 \mathrm{~A}$. The sequence boundary at about $170 \mathrm{mbsf}$ (ca. $0.92 \mathrm{Ma}$ ) separates a largely progradational seismic package below from a largely aggradational seismic package above (cf. Fig. 1). Two kinds of glauconite are observed based on degree of preservation: pristine and reworked. Pristine glauconite is associated with marine flooding surfaces and along condensed sections. Reworked glauconite is associated with toplapped and highstand systems tract progradation. See text for discussion. Nannofossil datums of Table 1 also are shown.

shortly following attainment of maximum flooding, percentages of shallow-water bioclast components diminished markedly. We attribute this to either subsequent drowning or landward-backstepping of these communities as sea level reached a maximum.

During highstand deposition, decreased accommodation potential promoted progressive progradation and sedimentation of reworked glauconites and terrigenous sands, silts, and clays. These depositional phases also were marked by progressive upsection increases in bioclastic components. We attribute these increases to highstand systems tract progradation and outbuilding of reef-derived material (Fig. 4).

\section{Microfossils}

Variations in total foraminifers, nannofossils, and tunicates also are shown in Figure 4. The variations in these components show a spiky character that in a general way appears to be grouped by abundance minima along sequence boundaries. The premise that microfossil abundances tend to show dramatic increases in association with maximum flooding and sequence condensation (Loutit et al., 1988; Vail et al., 1991) is not borne out, however, for the mixed sediments of the GBR transect. We postulate that this is because of the increase in importance of carbonate sedimentation at this setting relative to the dominance of siliciclastic detritus at sites where many previous sequence stratigraphic interpretations have been made (e.g., Loutit et al., 1988; Posamentier et al., 1988; Posamentier and Vail, 1988). In siliciclastic settings, sequence condensation is the natural result of the nearshore trapping of siliciclastic sands during maximum flooding. When this occurs, only fine-grained clays, minor silts, and open-marine pelagic sedimentation occur. Microfossils become relatively more abundant during these times, because they are less diluted by other sedimentary components; actual microfossil productivity may, however, remain relatively unchanged. Within the low-latitude, carbonate-dominated setting of the GBR, however, lower rates of terrigenous supply, combined with increased rain rates of pelagic microfossils, may be so pronounced that it becomes increasingly difficult to detect such an effect. Indeed, at these relatively remote sites, one can actually observe an increase in clay and silt in association with the downlapped surface (Fig. 4).

\section{Durations of Sea-level Cycles as Deduced from Sequence Stratigraphy}

Based on interpolated nannofossil age data (Table 1; also see Glenn et al., this volume), the duration of these sequences ranges from nearly third order (Sequence $5,443 \mathrm{ka}$ ) through fourth order (Sequence 1, $133 \mathrm{ka}$; Sequence 2, $146 \mathrm{ka}$; Sequence 3, $102 \mathrm{ka}$; Sequence 6, $173 \mathrm{ka}$; Sequence 7, $128 \mathrm{ka}$; Sequence 8, $249 \mathrm{ka}$; cycle order nomenclature after Wornardt and Vail, 1991). Of these, high sedimentation rates associated with Sequence 6 allow for its combined seismic and sedimentologic sequence-stratigraphic subdivision into three fifth-order parasequences (Sequences $6 \mathrm{~A}, 6 \mathrm{~B}, 6 \mathrm{C}$ ) with durations of 88,51 , and $34 \mathrm{ka}$, respectively. The maximum flooding surface of fifth-order Sequence 6B is coincident with the maximum flooding surface of fourth-order Sequence 6. Relatively low sedimentation rates associated with Sequence 5 do not permit subdivision of this unit on the basis of seismic data, nor on the basis of the bundling of 


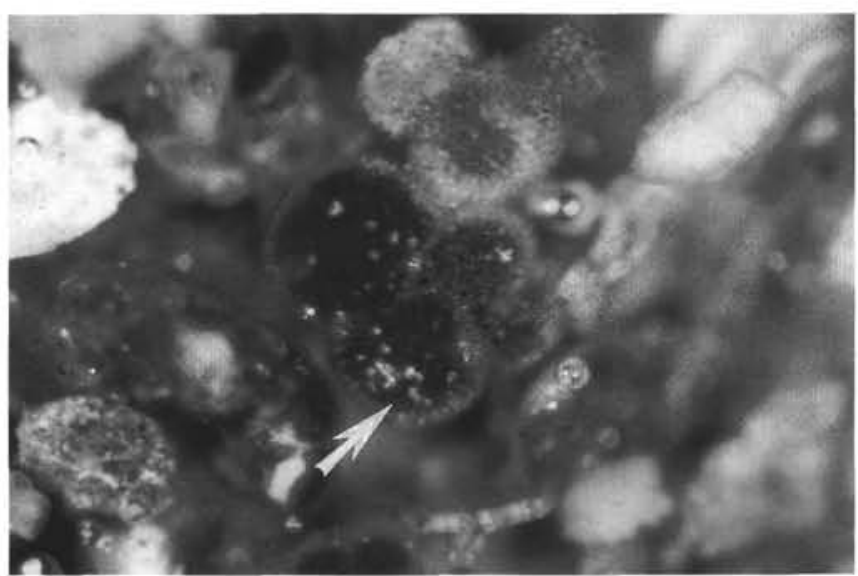

A

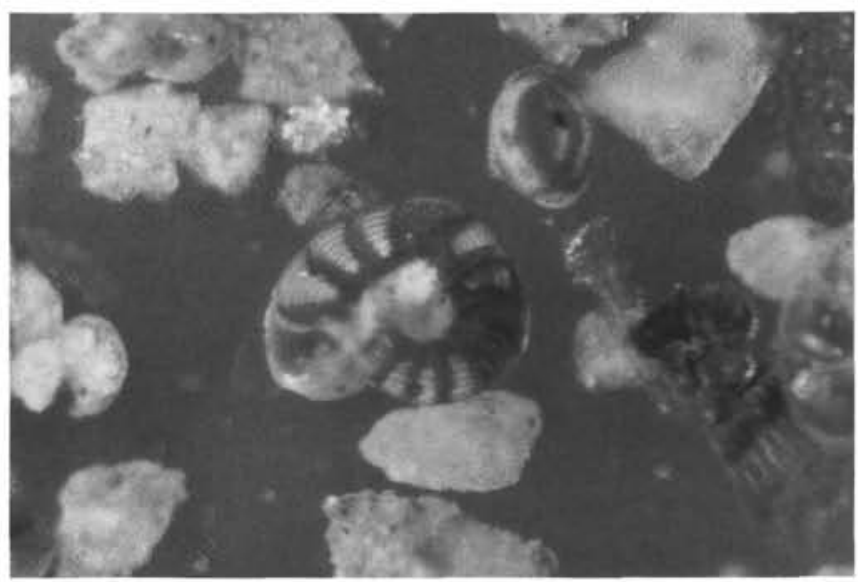

C

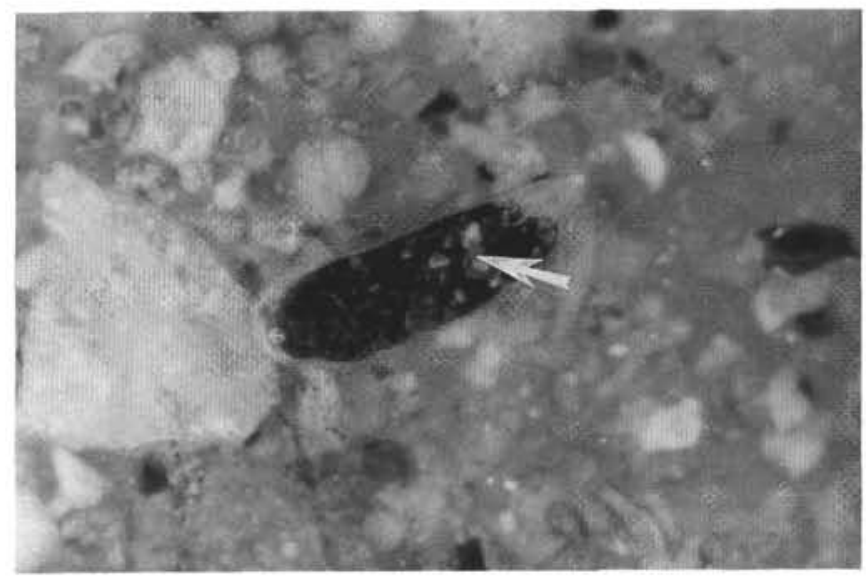

B

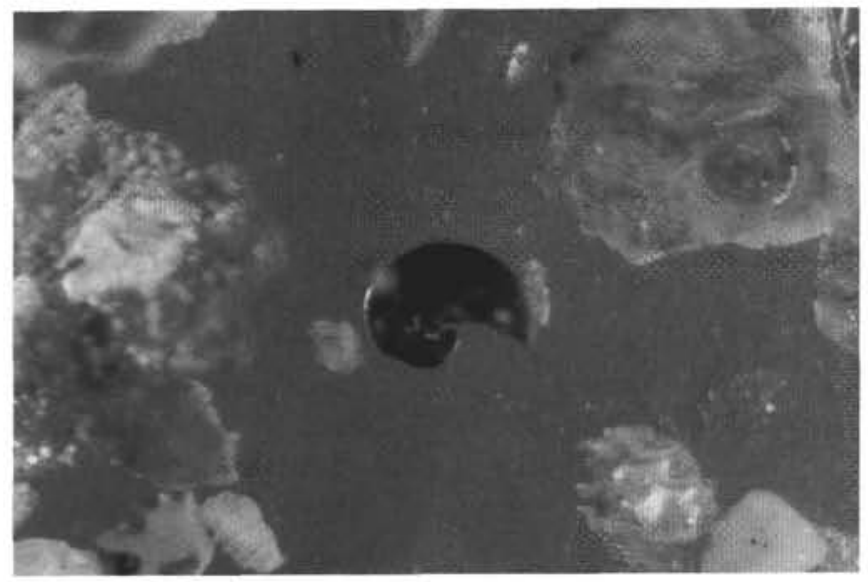

D

Figure 5. Smear slide photomicrographs of pristine glauconites from condensed sections in Hole 821B. A. Arrow points to planktonic foraminifer with glauconite infill; note delicate and undamaged architecture of test (Sample 133-821B-2H-1, 54-56 cm; horizontal dimension (HD) of photo $=1.25 \mathrm{~mm}$ ). B. Bioclast with glauconite replacing internal sediment; note foraminiferal tests (arrow) within the glauconite (Sample 133-821B-2H-1, 54-56 cm; HD =2.50 mm). C. Benthic foraminifer displaying early-stage glauconitization (Sample 133-821B-4H-6, 70-72 cm; HD =1.25 mm). D. Glauconitized gastropod (Sample 133-821B-4H-6, $70-72 \mathrm{~cm} ; \mathrm{HD}=1.25 \mathrm{~mm})$.

magnetic susceptibility-carbonate data. However, variations in glauconite, siliciclastics, and bioclasts suggest that this near third-order unit is composed of three or more higher-order sequences (Fig. 4).

\section{DISCUSSION}

\section{Significance of Condensed Sections}

Condensed sections, also known in the literature as condensed sequences and as beds that display stratigraphic condensation or sequence condensation, have been identified and have been the subject of investigation in numerous marine stratigraphic units found worldwide and of all ages postdating the Jurassic. These sections are of significance and interest, because they represent a process of extremely slow net sedimentation that continued over long periods of time. Since the 1930s and 1940s, such intervals have been recognized as characterized by the following features: (1) enrichment of well-preserved fossils and fossil fragments, (2) faunal mixing: fossils from different paleontological zones that were mixed up together within a bed, and (3) widespread distribution of sediments having negligible thicknesses (Heim, 1934; Rod, 1946). Since then, researchers have increasingly recognized that intervals of sequence condensation also frequently were marked by the occurrence and, in some instances, a high (even minable) abundance of authigenic minerals (e.g., Glenn and Arthur, 1988; Glenn, 1990). Of continuing debate, however, is how much sediment reworking and winnowing contributes to the condensation process (e.g., Rod, 1946; Jenkyns, 1971; Kennedy and Garrison, 1975; Krajewski, 1984; Kidwell, 1991; Glenn and Arthur, 1988; Glenn et al., 1988; Burnett et al., 1988; Glenn and Arthur, 1990; Föllmi, 1990; Snyder et al., 1990).

With the advent of sequence stratigraphy in the last two decades, condensed sections have taken on new meaning and significance as an integral component in the stratigraphic architecture of sequences controlled by fluctuations in relative sea level (Jervey, 1988; Posamentier et al., 1988; Posamentier and Vail, 1988). Loutit et al. (1988) and their colleagues defined condensed sections (in light of sequence stratigraphy) as thin marine units of pelagic to hemipelagic sediments that: (1) are characterized by very low sedimentation rates that are areally most extensive at the time of maximum transgression and coincident with the surface of maximum flooding, (2) are associated with apparent marine hiatuses, and (3) occur as omission surfaces or marine hardgrounds. Loutit et al. (1988) further stressed that condensed sections are important, because they tie the temporal stratigraphic framework found in open-ocean microfossil zonations to the physical stratigraphy of sequences in shallower continental margin sections. Today, condensed sections have become an integral part of a sequence, no matter how those sequences are defined. For example, Galloway (1989) (see also Schlager, 1991) provided an alternative approach to defining sequences as depositional systems containing 


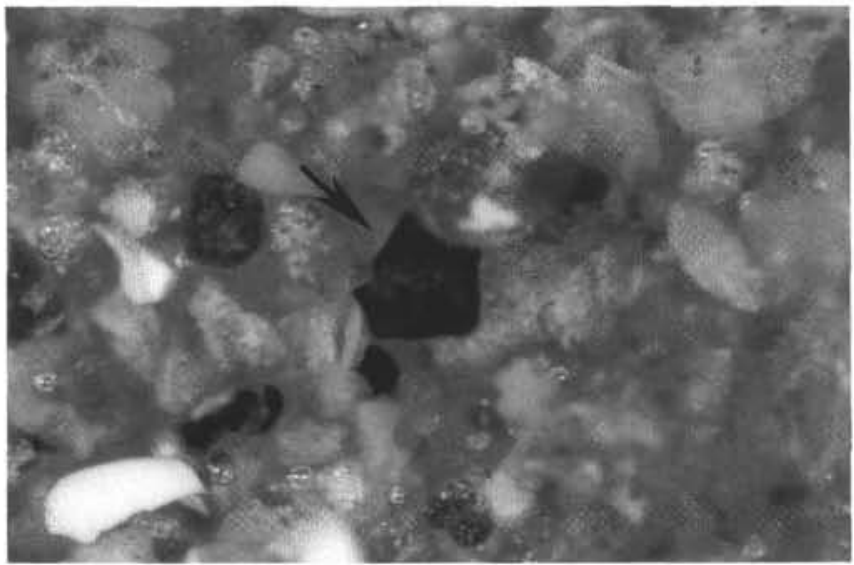

A

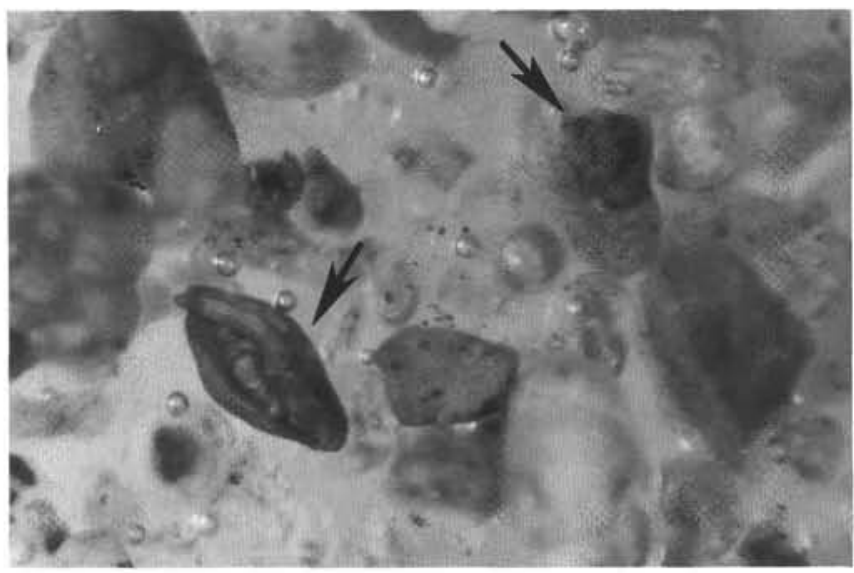

C

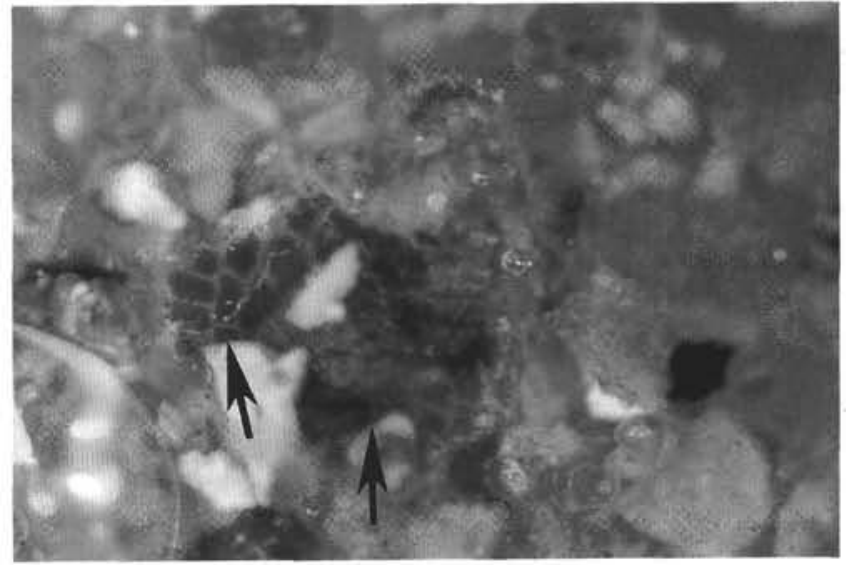

B

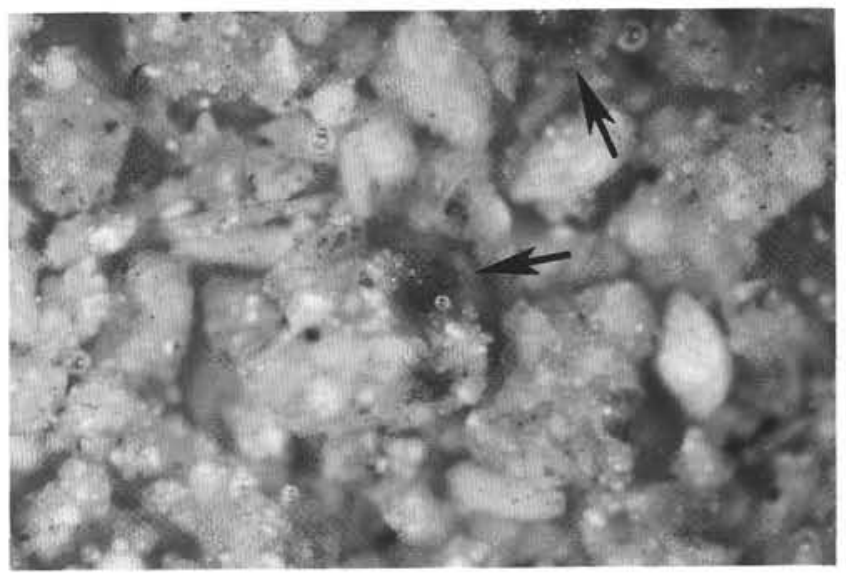

D

Figure 6. Smear slide photomicrographs of reworked glauconites from highstand systems tract in Hole 821B. A. Arrow points to reworked glauconite fragment (Sample 133-821B-10H-4, 70-72 cm; horizontal dimension $(\mathrm{HD})$ of photo $=1.25 \mathrm{~mm}$ ). B. Reworked and fragmented glauconitized foraminifer (Sample 133-821B-10H-4, 70-72 cm; HD = 1.25 mm). C. Arrows point to reworked and abraded glauconitized foraminifer $($ Sample $133-821 \mathrm{~B}-10 \mathrm{H}-4,70-72 \mathrm{~cm} ; \mathrm{HD}=$ $1.25 \mathrm{~mm}$ ). D. Reworked and abraded fragments of foraminifers, bioclasts, and micrite with some scattered reworked glauconite grains (arrows) (Sample 133-821B-13H-5, 70-72 cm; HD = $2.80 \mathrm{~mm}$ ).

bypass and erosional surfaces (sequence boundaries of Mitchum et al., 1977, and Van Wagoner et al., 1988) bounded by hiatal surfaces (preserved as submarine unconformities or condensed sections) that record maximum marine flooding. This "genetic sequence" provides an alternative sequence-stratigraphic unit that does not rely on the presence or recognition of widespread subaerial unconformities caused by eustatic and relative falls of sea level.

Seismic-based models recognize condensed sections that result from sediment starvation during times of maximum flooding. These occur along the break that separates the transgressive and highstand systems tracts. Assuming that seismic reflectors do indeed reflect time lines, sequence condensation may, hypothetically, also occur anywhere that reflectors converge, such as along surfaces of onlapping, back-stepping, downlapping, and toplapping (Fig. 7). For example, this may be reflected in outcrop studies that link condensed sections to a variety of shallow- and deep-water settings, to starvations that coincide with regressions characterized by sediment bypassing, and to transgression (e.g., Rod, 1946; Jenkyns, 1971; Einsele and Seilacher, 1982; Bayer and Seilacher, 1985; Kidwell, 1991). On the singular basis of temporal variations in glauconite abundance, our data suggest that sequence condensation is predominantly limited to marine flooding and maximum flooding surfaces in this mixed depositional setting. However, the systematic occurrence of reworked
Table 1. Summary of mean depths of biostratigraphic horizons from Sites 819,820 , and 821 .

\begin{tabular}{lcccc}
\hline \multicolumn{1}{c}{ Datum } & Age (Ma) & Site 819 & Site 820 & Site 821 \\
\hline & & & & \\
LO Emiliania Huxleyi acme & 0.08 & 8.4 & 12.1 & \\
LO Emiliania huxleyi & 0.275 & 29.4 & 35.8 & 39.3 \\
HO Psuedoemiliania lacunosa & 0.465 & 32.4 & 107.1 & 123.1 \\
HO Gephyrocapsa spp. C-D & 0.92 & 56.0 & 163.6 & 176.8 \\
HO Gephyrocapsa spp. A-B & 1.10 & 116.87 & 260.3 & 270.1 \\
HO Helicosphaera sellii & 1.27 & 189.2 & 271.7 & 279.2 \\
HO Calcidiscus macintyrei & 1.48 & $>400$ & $>400$ & $>400$
\end{tabular}

Notes: Biostratigraphic age assignments updated from Berggren et al., 1985. The age scales calculated for these cores assume a constant sedimentation rate between each age datum. $\mathrm{LO}=$ lowest occurrence, $\mathrm{HO}=$ highest occurrence.

glauconites within the upper portions of highstand systems tracts also may reflect relatively minor episodes of starvation and bypassing that occur in association with toplapping deposits (Fig. 7). In this portion of the highstand systems tract, sequence condensation may be common because here toplapping reflectors (time lines) converge. In sum, the actual distribution of condensed deposits within siliciclastic and mixed carbonate/siliciclastic sequences is probably more complex than has been depicted by recent models. 


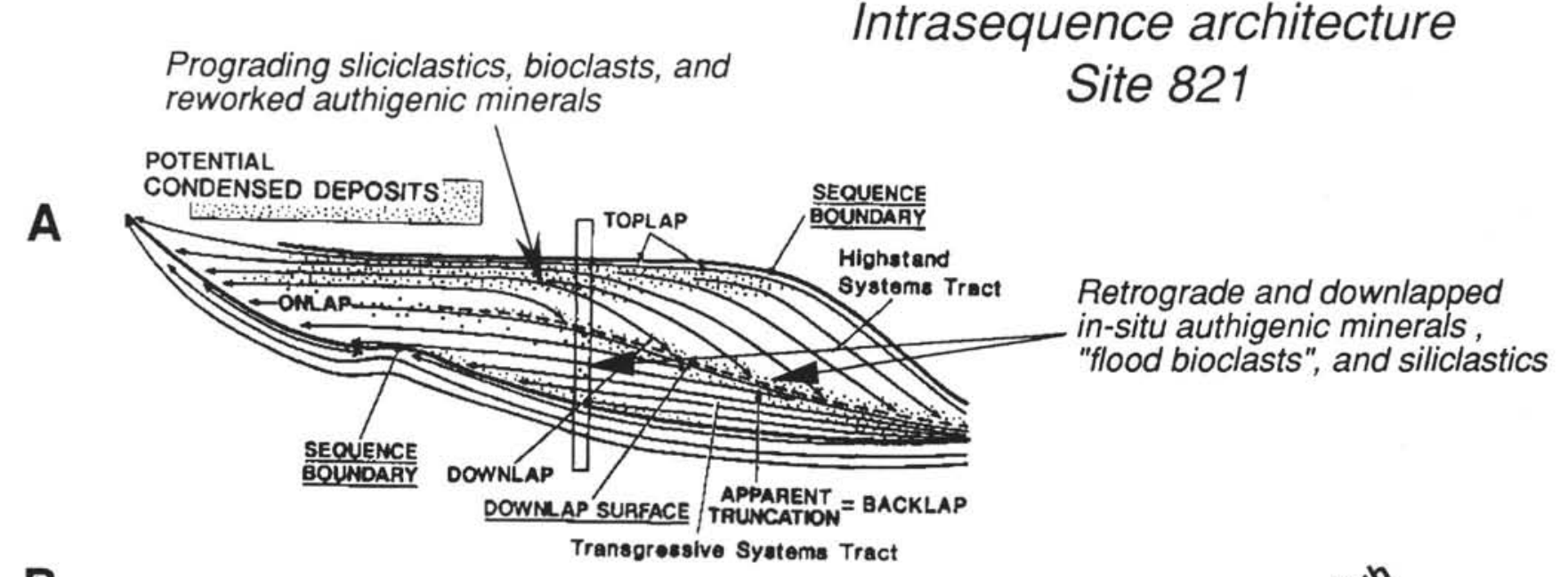

B
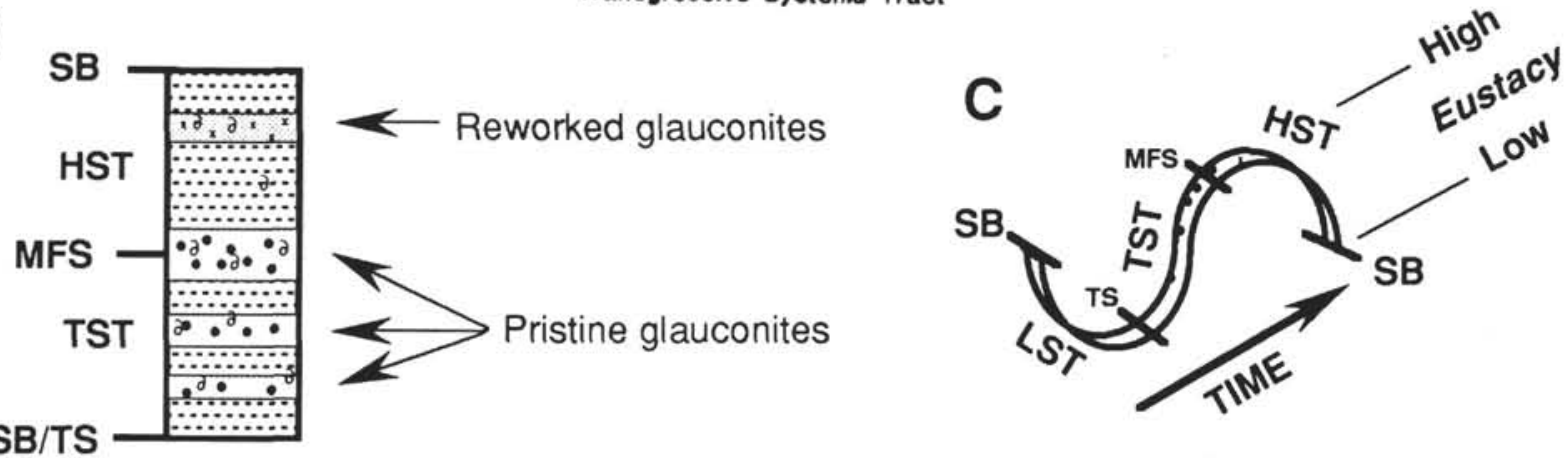

Figure 7. Intrasequence architecture at Site 821. A. Possible positions of sequence condensation within an idealized depositional sequence (stipples) (after Kidwell, 1991). B. Schematic illustration of the placement of nonreworked pristine and reworked glauconites recovered at Site 821. Pristine glauconites form within transgressive systems tracts and at the maximum flooding surface, whereas reworked glauconites are found within highstand systems tracts. C. The timing of systems tracts development with respect to one cycle of sea-level change. LST $=$ lowstand systems tract, TST $=$ transgressive systems tract, HST $=$ highstand systems tract, TS = transgressive surface, MFS = maximum flooding surface, $\mathrm{SB}=$ sequence boundary. Dots on the sea-level curve represent locations of glauconite.

\section{Significance of Glauconite in Condensed Sections}

Glauconites occur mainly in water depths of 100 to $500 \mathrm{~m}$ on modern seafloors and can make up $10 \%$ to $90 \%$ of the sediments of the outer shelf and upper slope between water depths of 200 and $300 \mathrm{~m}$ (Odin and Matter, 1981), although some of these may be relict. Glauconites are mineralogically diverse because of highly variable physical and chemical properties; their formation appears to be controlled by a delicate balance between degree of physical confinement and the amount of ionic exchange between the microenvironment, such as within foraminiferal shells, and ambient open seawater (Odin and Matter, 1981). In addition, they may form directly from pore waters within suboxic bacterial zones in association with iron reduction (Glenn and Arthur, 1988; 1990). Glauconites are unique, because they contain iron in both its reduced and oxidized states, and are thus characteristic of weakly oxidizing to mildly reducing marine environments (cf. Glenn and Arthur, 1988; 1990). This prerequisite appears to dictate where and when glauconite may form. During early diagenesis of marine sediments, iron may be reduced and solubilized by ironreducing bacteria within the zone of suboxic diagenesis (cf. Froelich et al., 1979; Berner, 1980) or within the microreducing environments provided by foraminifer tests. We think the reason glauconites are so typically encountered within condensed intervals is because slow rates of sedimentation effectively increase the residence time for particles before they encounter the more fully reducing conditions associated with bacterial sulfate reduction; when this takes place, sulfate is reduced to produce sulfide, which rapidly sequesters available reduced iron to form pyrite, not glauconite. Slow rates of sedimentation (and organic carbon accumulation) effectively expand the zone of suboxic diagenesis and increase the length of time a given parcel of sediment will have before encountering dissolved sulfide at depth.

\section{Climatic Overprints}

In this compilation, we have assumed that sequence-stratigraphic architectures observed along the GBR transect are a result of variations in accommodation potential that result from the interplay between subsidence, sediment supply, and changes in eustatic sea level. We have, however, largely ignored another major variable that may have greatly impacted sedimentation in this area during the past 1.5 Ma: climate. Collectively, the data presented here indicate that condensed sections within the GBR transect are thin units that occur along downlapped surfaces and that are characterized by increases in clays and quartz, pristine glauconite, and shallow-water bioclasts. We interpret the abundance of glauconite to reflect overall diminished sedimentation rates and attribute the abundance of bioclasts to the establishment and initial flourishing of shallow-water reefal communities along the outer margin during marine flooding. In light of the general interpretation procedures of sequence stratigraphy, increases in clays and quartz during these times seem somewhat puzzling; these models generally depict a minimum in the influence of terrigenous sedimentation during these times. We suggest, therefore, that the reason for this apparent dichotomy is related to sedimentary overprinting caused by climate change.

We envision two possible scenarios that may explain the increases in clays and quartz in association with maximum flooding at these 
sites. It remains possible that, accompanying maximum flooding, hinterlands were exposed to increases in rainfall and weathering, and that terrigenous components thus were increasingly flushed toward the basin during these times. Our preferred interpretation, however, is that clays represent sediment starvation, and that the quartz we are observing in these sections may represent a background eolian component that becomes relatively concentrated during times of sequence condensation. Clays are typical of most condensed sections because during times of maximum flooding most siliciclastic detritus is trapped in nearshore depositional settings. Today, dust storms in Australia are a vast source for eolian sediments and also are capable of transporting large particles. For example, a large storm in 1928 carried an average distribution of up to $30 \mathrm{~g} / \mathrm{m}^{2}$ over New Zealand, about $2000 \mathrm{~km}$ away (Glasby, 1971). A significant thrust of our ongoing study of these sediments is aimed at trying to differentiate these possible mechanisms (cf. Glenn et al., this volume).

\section{Temporal Validity}

Our evidence for sequence condensation within these sediments has been somewhat artificial, because we have, in fact, no actual temporal data to indicate that the sediments along downlapped surfaces represent hiatuses or abnormally long periods of geologic time. This is because our biostratigraphic zonations are much wider than the spacings of the stratigraphic sequences they contain. The inference that the thin units associated with the downlapped surfaces reflect episodes of sequence condensation is based on recent sequence-stratigraphic models and the common association between significant accumulations of glauconites and other authigenic mineral phases and markedly reduced sedimentation rates in the geologic record. Further testing of the true temporal significance of these horizons awaits refined age dating.

\section{SUMMARY AND CONCLUSIONS}

1. Great Barrier Reef forereef sediments contain a high-resolution Pleistocene record of mixed siliciclastic-carbonate sedimentation.

2. Nine sequences are recognizable from available seismic data and have been penetrated by drilling. Based on interpolated nannofossil age data, the duration of these sequences ranges from nearly third order (Sequence 5, $443 \mathrm{ka}$ ) through fourth order (Sequence 1, $133 \mathrm{ka}$; Sequence 2, $146 \mathrm{ka}$; Sequence 3,102 ka; Sequence 6, $173 \mathrm{ka}$; Sequence 7, $128 \mathrm{ka}$; Sequence 8, $249 \mathrm{ka}$ ). Of these, high sedimentation rates associated with Sequence 6 allow for its combined seismic and sedimentologic sequence stratigraphic subdivision into three fifth-order parasequences (Sequences 6A, 6B, 6C) with durations of 88,51 , and $34 \mathrm{ka}$, respectively. The maximum flooding surface of fifth-order Sequence $6 \mathrm{~B}$ is coincident with the maximum flooding surface of fourth-order Sequence 6. Relatively low sedimentation rates associated with Sequence 5 do not permit subdivision of this unit on the basis of seismic data, nor on the basis of the bundling of carbonate-magnetic susceptibility data. However, variations in glauconite, siliciclastics, and bioclasts suggest that this near third-order unit is composed of three or more higher-order sequences.

3. Terrigenous influx to the GBR forereef setting, as indicated by simultaneous increases in magnetic susceptibility, insoluble residues, gamma-ray activity, and siliciclastic sands, dramatically increased during discreet flooding events and reached a maxima in association with maximum flooding along downlapped surfaces resolvable in seismic data. In traditional sequence stratigraphic interpretations, these downlapped surfaces mark maximum episodes of sequence condensation and terrigenous starvation within each systems tract. The data presented here, however, suggest that, within this mixed terrigenous-carbonate depositional setting, rates of terrigenous input reached a maxima during these times. We suggest that this input is climate modulated.
4. Increases in terrigenous influx during flooding events also are characterized by increases in authigenic glauconite mineralization and increases in shallow-water bioclast influx. At these positions, proportions of shallow-water bioclasts increase despite decreases in total carbonate contents.

5. Increases in bioclasts within transgressive systems tracts are attributed to relatively rapid buildups of shallow-water reefal communities that accompanied punctuated flooding events. Although the percentage of total carbonate decreased during these episodes, we suggest that during these times shallow-water carbonate growth accelerated as reefal communities built upward rapidly to keep up with rising sea level. These rapid buildups are akin to the keep-up carbonate complexes of Kendall and Schlager (1981) and Sarg (1988).

6. Upon, or shortly following, attainment of maximum flooding, percentages of shallow-water bioclast components diminished markedly. These decreases in bioclasts have been interpreted as the result of either the progressive or incipient drowning of shallow-water reefs (cf. Kendall and Schlager, 1981) or their landward back-stepping away from the forereef depositional sites.

7. Decreased accommodation potential during relative highstand phases promoted progressive highstand systems tract progradation and sedimentation of reworked glauconites and terrigenous sands, silts, and clays. These depositional phases also were marked by increases in bioclastic sands that accompanied progradational, seaward building events.

8. Increases in microfossil abundances do not appear to relate to formation of condensed sections in this mixed carbonate-terrigenous depositional setting.

9. However, whereas the relative rising and falling of sea level predicted from our data are internally consistent, the relative coarseness of biostratigraphic datums, the general paucity of lowstand systems tracts at Site 821, and our assumptions of constant thermal subsidence make references to the absolute timings of flooding events tenuous. Thus, correspondence of these awaits refined age control and testing relative to other, similarly resolvable, continental margin records.

\section{ACKNOWLEDGMENTS}

Financial support for this project was provided by grants from the U.S. Scientific Advisory Committee (USSAC). We thank Gregory Moore and Michael Arthur for helpful discussions and Karl Föllmi and Isabel Montañez for thorough reviews of the manuscript. To our co-chiefs, colleagues, and the ship and drilling crews of JOIDES Resolution, we express our gratitude for their helpfulness and cooperation. This is a contribution to IGCP Project 325 Paleoceanography and Authigenic Minerals and is UH SOEST Contribution No. 3172.

\section{REFERENCES $*$}

Bayer, U., and Seilacher, A. (Eds.), 1985. Sedimentary and Evolutionary Cycles: Berlin (Springer-Verlag), Lecture Notes and Earth Sci., I.

Berggren, W.A., Kent, D.V., and Van Couvering, J.A., 1985. The Neogene: Part 2. Neogene geochronology and chronostratigraphy. In Snelling, N.J. (Ed.), The Chronology of the Geological Record. Geol. Soc. London Mem., 10:211-260.

Berner, R.A., 1980. Early Diagenesis: A Theoretical Approach: Princeton, NJ (Princeton Univ. Press).

Brown, L.F., and Fisher, W.L., 1977. Seismic stratigraphic interpretation of depositional systems. In Payton, C.E. (Ed.), Seismic Stratigraphy: Applications to Hydrocarbon Exploration. AAPG Mem., 26:213-248.

Burnett, W.C., Baker, K.B., Chin, P.A., McCabe, W., and Ditchburn, R., 1988. Uranium-series and AMS ${ }^{14} \mathrm{C}$ studies of modern phosphatic pellets from Peru shelf muds. Mar. Geol., 80-3/4:215-230.

\footnotetext{
"Abbreviations for names of organizations and publications in ODP reference lists follow the style given in Chemical Abstracts Service Source Index (published by American Chemical Society).
} 
Einsele, G., and Seilacher, A. (Eds.), 1982. Cycle and Event Stratification: Berlin (Springer-Verlag).

Engleman, E.E., Jackson, L.L., and Norton, D.R., 1985. Determination of carbonate carbon in geological materials by coulometric titration. Chem. Geol., 53:125-128.

Feary, D.A., Pigram, C.J., Davies, P.J., Symonds, P.A., Droxler, A.W., and Peerdeman, F., 1990. Ocean Drilling Program-Leg 133 safety package. Bur. Miner. Res. Aust. Rec., 1990/6.

Föllmi, K.B., 1990. Condensation and phosphogenesis; example of the Helvetic mid-Cretaceous (northern Tethyan margin). In Notholt, A.J.G., and Jarvis, I. (Eds.), Phosphorite Research and Development. Geol. Soc. Spec. Publ. London, 52:237-252.

Froelich, P.N., Klinkhammer, G.P., Bender, M.L., Luedtke, N.A., Heath, G.R., Cullen, D., Dauphin, P., Hartman, B., Hammond, D., and Maynard, V., 1979. Early oxidation of organic matter in pelagic sediments of the eastern Equatorial Atlantic: suboxic diagenesis. Geochim. Cosmochim. Acta, 43:1075-1090.

Galloway, W.E., 1989. Genetic stratigraphic sequences in basin analysis I: architecture and genesis of flooding-surface bounded depositional units. AAPG Bull., 73:125-142.

Glasby, G.P., 1971. The influence of aeolian transport of dust particles on marine sedimentation in the Southwest Pacific. J. R. Soc. N.Z., 1:285-300.

Glenn, C.R., 1990. Depositional sequences of the Duwi, Sibaiya and Phosphate formations, Egypt: phosphogenesis and glauconitization in a Late Cretaceous epeiric sea. In Notholt, A.J.G., and Jarvis, I. (Eds.), Phosphorite Research and Development. Geol. Soc. Spec. Publ. London, $52: 205-222$.

Glenn, C.R., and Arthur, M.A., 1988. Petrology and major element geochemistry of Peru margin phosphorites and associated diagenetic minerals: authigenesis in modern organic-rich sediments. Mar. Geol., 80-3/4:231-267.

1990. Anatomy and origin of a Cretaceous phosphorite-greensand giant, Egypt. Sedimentology, 37:123-154.

Glenn, C.R., Arthur, M.A., Yeh, H.W., and Burnett, W.C., 1988. Carbon isotopic composition and lattice-bound carbonate of Peru-Chile margin phosphorites. Mar. Geol., 80-3/4:287-307.

Haq, B.U., 1991. Sequence stratigraphy, sea-level change, and significance for the deep sea. Spec. Publs. Int. Assoc. Sedimentol., 12:1-36.

Heim, A.A., 1934. Stratigraphische Kondensation. Eclogae Geol. Helv., 27:372-383.

Huffman, E.W.D., 1977. Performance of a new automatic carbon dioxide coulometer. Microchem. J., 22:567-573.

Jenkyns, H.C., 1971. The genesis of condensed sequences in the Tethyan Jurassic. Lethaia, 4:327-352.

Jervey, M.T., 1988. Quantitative geological modeling of siliciclastic rock sequences and their seismic expression. In Wilgus, C.K., Hastings, B.S., et al. (Eds.), Sea-Level Changes: An Integrated Approach. Spec. Publ.Soc. Econ. Paleontol. Mineral., 42:47-69.

Kendall, C.G.St.C., and Schlager, W., 1981. Carbonates and relative changes in sea level. Mar. Geol., 44:181-212.

Kennedy, W.J., and Garrison, R.E., 1975. Morphology and genesis of nodular phosphates in the Cenomanian glauconite marl of South East England. Lethaia, 8:339-360.

Kidwell, S.M., 1991. Condensed deposits in siliciclastic sequences: expected and observed features. In Einsele, G., Ricken, W., and Seilacher, A. (Eds.), Cycles and Events in Stratigraphy: Berlin (Springer-Verlag), 682-695.

Krajewski, K.P., 1984. Early diagenetic phosphate cements in the Albian condensed glauconitic limestone of the Tatra Mountains, Western Carpathians. Sedimentology, 31:443-470.

Loutit, T.S., Hardenbol, J., Vail, P.R. and Baum, G.R., 1988. Condensed sections: the key to age determination and correlation of continental margin sequences. In Wilgus, C.K., Hastings, B.S., et al. (Eds.), Sea-Level Changes: An Integrated Approach. Spec. Publ.-Soc. Econ. Paleontol. Mineral., 42:183-213.
Mitchum, R.M., Jr., Vail, P.R., and Thompson, S., III, 1977. Seismic stratigraphy and global changes of sea level, Part 2: the depositional sequence as a basic unit for stratigraphic analysis. In Payton, C.E. (Ed.), Seismic Stratigraphy-Applications to Hydrocarbon Exploration. AAPG Mem., 26:53-62.

Odin, G.S., and Matter, A., 1981. Die glauconarium origine. Sedimentology, 28:611-643.

Posamentier, H.W., Jervey, M.T., and Vail, P.R., 1988. Eustatic control on clastic deposition. I: conceptual framework. In Wilgus, C., Hastings, B.S., Kendall, C.G.S.C., Posamentier, H.W., Ross, C.A., and Van Wagoner, J.C. (Eds.), Sea-level Changes: An Integrated Approach: Spec. Publ.-Soc. Econ. Paleontol. Mineral., 42:109-124.

Posamentier, H.W., and Vail, P.R., 1988. Eustatic controls on clastic deposition. II-sequence and systems tract models. In Wilgus, C.K., Hastings, B.S., et al. (Eds.), Sea-Level Changes: An Integrated Approach. Spec. Publ.Soc. Econ. Paleontol. Mineral., 42:124-154.

Rod, E., 1946. Uber ien fossillager in oberen Malm der Melchtaleralpen. Eclogae Geol. Helv, 39:177-198.

Sarg, J.F., 1988. Carbonate sequence stratigraphy. In Wilgus, C.K., Hastings, B.S., Kendall, C.G.St.C., Posamentier, H.W., Ross, C.A., and Van Wagoner, J.C. (Eds.), Sea-Level Changes: An Integrated Approach. Spec. Publ.-Soc. Econ. Paleontol. Mineral., 42:155-181.

Schlager, W., 1991. Depositional bias and environmental change-important factors in sequence stratigraphy. Sediment. Geol., 70:109-130.

Snyder, S.W., Hine, A.C., and Riggs, S.R., 1990. Carolina continental margin: Part 2. The seismic stratigraphic record of shifting Gulf Stream flow paths in response to Miocene glacio-eustasy: implications for phosphogenesis along the North Carolina continental margin. In Burnett, W.C., and Riggs, S.R. (Eds.), Phosphate Deposits of the World (Vol. 3): Cambridge (Cambridge Univ. Press), 396-423.

Symonds, P.A., Davies, P.J., and Parisi, A., 1983. Structure and stratigraphy of the central Great Barrier Reef. BMR J. Aust. Geol. Geophys., 8:277-291.

Vail, P.R., 1990. Sequence stratigraphic interpretation of seismic, well and outcrop data. AAPG Short Course.

Vail, P.R., Audemard, F., Bowman, S.A., Eisner, P.N., and Perez-Cruz, G., 1991. The stratigraphic signatures of tectonics, eustasy, and sedimentation. In Einsele, G., Ricken, W., and Seilacher, A. (Eds.), Cycles and Events in Stratigraphy: Amsterdam (Elsevier), 617-681.

Vail, P.R., Todd, R.G., and Sangree, J.B., 1977. Seismic stratigraphy and global changes of sea level, Part 5: chronostratigraphic significance of seismic reflections. In Payton, C.E. (Ed.), Seismic Stratigraphy-Applications to Hydrocarbon Exploration. AAPG Mem., 26:99-116.

Van Wagoner, J.C., Mitchum, R.M., Campion, K.M., and Rahmanian, V.D., 1990. Siliciclastic Sequence Stratigraphy in Well Logs, Cores, and Outcrops: Concepts for High-Resolution Correlation of Time and Facies. AAPG, Methods Explor. Ser., 7.

Van Wagoner, J.C., Posamentier, H.W., Mitchum, R.M., Vail, P.R., Sarg, J.F., Loutit, T.S., Hardenbol, J., 1988. An overview of the fundamentals of the sequence stratigraphy and key definitions. In Wilgus, C.K., Hastings, B.S., Kendall, C.G.St.C., Posamentier, H.W., Ross, C.A., and Van Wagoner, J.C. (Eds.), Sea-Level Changes: An Integrated Approach. Spec. Publ.-Soc. Econ. Paleontol. Mineral., 42:39-45.

Wornardt, W.W., and Vail, P.R., 1991. Tentative revision of the global Pliocene-Pleistocene Sequences based on sequence stratigraphy in the Gulf of Mexico. AAPG Bull., 75:1425.

Date of initial receipt: 28 April 1992

Date of acceptance: 10 December 1992 Ms 133SR-241 